\title{
PENGEMBANGAN SISTEM MANAJEMEN PROYEK PADA SMART CITY AND COMMUNITY INNOVATION CENTER ITB
}

\author{
Abdul Salam ${ }^{1}$ \\ Budi Maryanto ${ }^{2}$ \\ Sekolah Tinggi Manajemen Informatika dan Komputer \\ LIKMIJI. Ir. H. Juanda no 96 Bandung \\ abdulsalam121196@gmail.com ${ }^{1}$ \\ budimaryanto@likmi.ac.id
}

\begin{abstract}
ABSTRAK
Kebutuhan utama institusi yang menangani proyek terutama adalah dalam hal manajemen sumber daya : bagaimana sumber daya yang tersedia dapat digunakan secara efektif sehingga target proyek dapat tercapai dengan baik dan tepat waktu. Seringkali muncul kesulitan dalam tracking progress suatu taks/tugas, serta pendelegasian task/tugas per proyek yang tidak menentu, sehingga mengakibatkan kerugian jangka panjang bagi institusi yang bersangkutan.

Artikel ini akan memaparkan pengembangan sistem manajemen proyek di Smart City And Community Innovation Center (SCCIC) ITB. Sistem akan menangani manajemen task/tugas, laporan kemajuan proyek atau task/tugas, pendelegasian anggota yang terlibat, hingga pengajuan tiket/ticket (berupa error, bug, question, dan lainnya) untuk tiap task/tugas. Sistem akan dibangun dengan metodologi berbasis object. Beberapa diagram UML digunakan sebagai perangkat pemodelan sistem.
\end{abstract}

Kata kunci : manajemen proyek, pemantauan kemajuan proyek, task, ticket.

\section{PENDAHULUAN}

Sebagai sebuah institusi yang banyak menangani proyek pembangunan sistem, Tim Developer SCCIC banyak menemui permasalahan-permasalahan sebagai berikut :

a. Pengembangan proyek tanpa tools pendukung, sehingga proses pendelegasian dan penentuan pekerjaan masih dilakukan secara manual melalui briefing tiap saat pengerjaan proyek.

b. Kebingungan terhadap tasks/tugas yang harus dikerjakan perhari-nya, jika 1 tasks/tugas selesai, maka tasks/tugas berikutnya harus bertanya pada Project Learder/Manager yang bersangkutan. Adapun jika pihak yang bersangkutan tidak masuk/izin, maka proyek yang sedang dikerjakan akan menjadi tertahan/terhambat (on holding).

c. Tidak ada penetapan tasks/tugas proyek yang mendetail, yang bisa memberi acuan dan panduan pada anggota proyek untuk mengetahui status proyek atau tasks yang sedang/akan dikerjakan.

d. Kesulitan bagi pekerja baru atau anggota yang baru dimasukkan divisi tertentu untuk mengerjakan proyek tertentu, karena penentuan pekerjaan yang menyulitkan, ketika diberi proyek pengembangan yang harus ditambah atau 
modifikasi fitur, tanpa mengetahui progress sebelumnya dari proyek ybs., dan dokumentasi pengembangan sebelumnya.

e. Tidak adanya info pembaharuan/kemajuan terhadap tasks/tugas yang sedang dikerjakan, sehingga seringkali terjadi bentrok pekerjaan dan pengulangan (buat ulang) pengerjaan tasks/tugas diantara anggota proyek.

Oleh karena itu muncul kebutuhan untuk merancang sistem manajemen proyek yang diharapkan dapat memberikan kemudahan dan aksesibilitas sebagai berikut:

a. Mempermudah penelurusan kemajuan tasks/tugas terhadap proyek yang diberikan atau berjalan.

b. Memaksimalkan potensi tim sehingga proses pengerjaan suatu proyek menjadi efektif dan tidak adanya kemungkinan terjadi pengulangan pekerjaan.

c. Mempermudah pembagian kerja para pengembang, desainer, unit tester, dan kesatuan tim proyek lainnya karena adanya requirement dan pembagian tugas yang jelas.

d. Pelaksanaan pekerjaan menjadi teratur dan sesuai dengan jadwal dan biaya yang telah ditentukan, sehingga proyek memenuhi batasan waktu dan biaya yang diminta.

e. Pelacakan bugs atau errors dan pelaporan yang sifatnya perubahan dapat diatasi secara cepat, karena sistem akan menangani request of changes dari proyek yang sedang dikerjakan.

f. Melakukan otomasi terhadap seluruh proyek yang ada di Smart City and Community Innovation Center ITB.

g. Adanya recovery data terhadap proyek yang sedang dikerjakan/dikembangkan.

h. Mampu melakukan pelacakan terhadap pengembangan proyek yang terhambat, selesai, dibatalkan, dan lainnya.

\section{MANAJEMEN PROYEK}

Proyek merupakan rangkaian aktivitas untuk mencapai suatu tujuan (obyektif) tertentu sesuai dengan harapan klien. Obyektif yang ingin dicapai bisa berupa pengembangan produk kongkrit (berwujud) ataupun bentuk lainnya yang tidak berwujud seperti perangkat lunak.

Menurut Schwalbe [1], suatu proyek dibatasi dengan ruang lingkup (scope), waktu (time) dan biaya (cost). Dengan kata lain, ada keterbatasan sumber daya (resource), sehingga diperlukan upaya sungguh-sungguh untuk mengelola alokasi sumber daya ini secara optimal.

Terdapat tahapan-tahapan utama yang harus dilakukan dalam siklus hidup pengerjaan sebuah proyek [1], yaitu meliputi :

a. Tahap Inisiasi

Tahap inisiasi proyek merupakan langkah awal kegiatan proyek sejak suatu proyek disepakati untuk dikerjakan. Pada tahap ini, permasalahan akan diidentifikasi. Beberapa pilihan solusi untuk menyelesaikan permasalahan juga didefinisikan. Sebuah studi kelayakan dapat dilakukan untuk memilih sebuah solusi yang memiliki kemungkinan terbesar untuk direkomendasikan sebagai solusi terbaik dalam menyelesaikan permasalahan. Ketika sebuah solusi telah ditetapkan, maka seorang manajer proyek akan ditunjuk sehingga tim proyek dapat dibentuk.

b. Tahap Perencanaan

Ketika ruang lingkup proyek telah ditetapkan dan tim proyek terbentuk, maka aktivitas proyek mulai memasuki tahap perencanaan. Pada tahap ini, dokumen perencanaan akan disusun secara terperinci sebagai panduan bagi tim proyek selama kegiatan pengerjaan proyek berlangsung. Adapun aktivitas yang akan dilakukan pada tahap ini adalah membuat dokumentasi project plan, resource plan, financial plan, risk plan, acceptance plan, communication plan, procurement plan, contract supplier dan perform phare review. 
c. Tahap Eksekusi (Pelaksanaan proyek)

Dengan definisi proyek yang jelas dan terperinci, maka aktivitas proyek siap untuk memasuki tahap eksekusi. Pada tahap ini, deliverables atau tujuan proyek secara fisik akan dibangun. Seluruh aktivitas yang terdapat dalam dokumentasi project plan akan dieksekusi. Sementara kegiatan pengembangan berlangsung, beberapa proses manajemen perlu dilakukan untuk memantau dan mengontrol penyelesaian dari deliverables sebagai hasil akhir proyek.

d. Tahap Penutupan

Tahap ini merupakan akhir dari aktivitas proyek. Pada tahap ini, hasil akhir proyek (deliverables project) beserta dokumentasinya diserahkan kepada pengguna, kontak dengan supplier diakhiri, tim proyek dibubarkan dan memberikan laporan kepada semua stakeholder yang menyatakan bahwa kegiatan proyek telah selesai dilaksanakan. Langkah akhir yang harus dilakukan pada langkah ini yaitu melakukan post implementation review untuk meninjau tingkat keberhasilan proyek dan mencatat setiap pengalaman yang diperoleh selama aktivitas proyek berlangsung sebagai pengalaman untuk proyek dimasa yang akan datang.

e. Organisasi proyek

Ini adalah tahapan suatu proyek sebelum ditutup (penyelesaian). Meskipun demikian, tidak semua proyek akan melewati setiap tahap, artinya proyek dapat dihentikan sebelum mencapai pengakhiran. Beberapa proyek tidak mengikuti perencanaan terstruktur atau proses pengamatan. Sebagian besar proyek akan melalui tahapan tersebut secara berulang (iteratif).

\section{ANALISIS KEBUTUHAN SISTEM}

Berikut ini adalah cakupan kebutuhan sistem untuk pengelolaan proyek secara terintegrasi :

a. Pengadaan/ penerimaan proyek

b. Penjadwalan proyek

c. Penugasan/ pendelegasian anggota tim proyek

d. Penetapan task

e. Pemantauan (monitoring) kemajuan proyek

f. Pengelolaan ticket (bug, question dan sebagainya)

g. Pembaharuan (error tracking) proyek

h. Pelaporan (reporting) proyek

Gambar 1 menampilkan diagram System Use Case yang mendeskrisikan kebutuhan sistem manajemen proyek di SCCIC ITB. Setiap use case mewakili suatu proses bisnis utama. Untuk merinci aktivitas yang terdapat dalam sebuah use case, digunakan diagram aktivitas (activity diagram). Gambar 2 s/d 4 mewakili sebagian dari activity diagram. Gambar 2 berisi detil aktivitas registrasi pengguna (user). Gambar 3 memaparkan rincian pengelolaan jadwal harian. Sedangkan Gambar 4 menampilkan tahapan untuk mengelola task. 


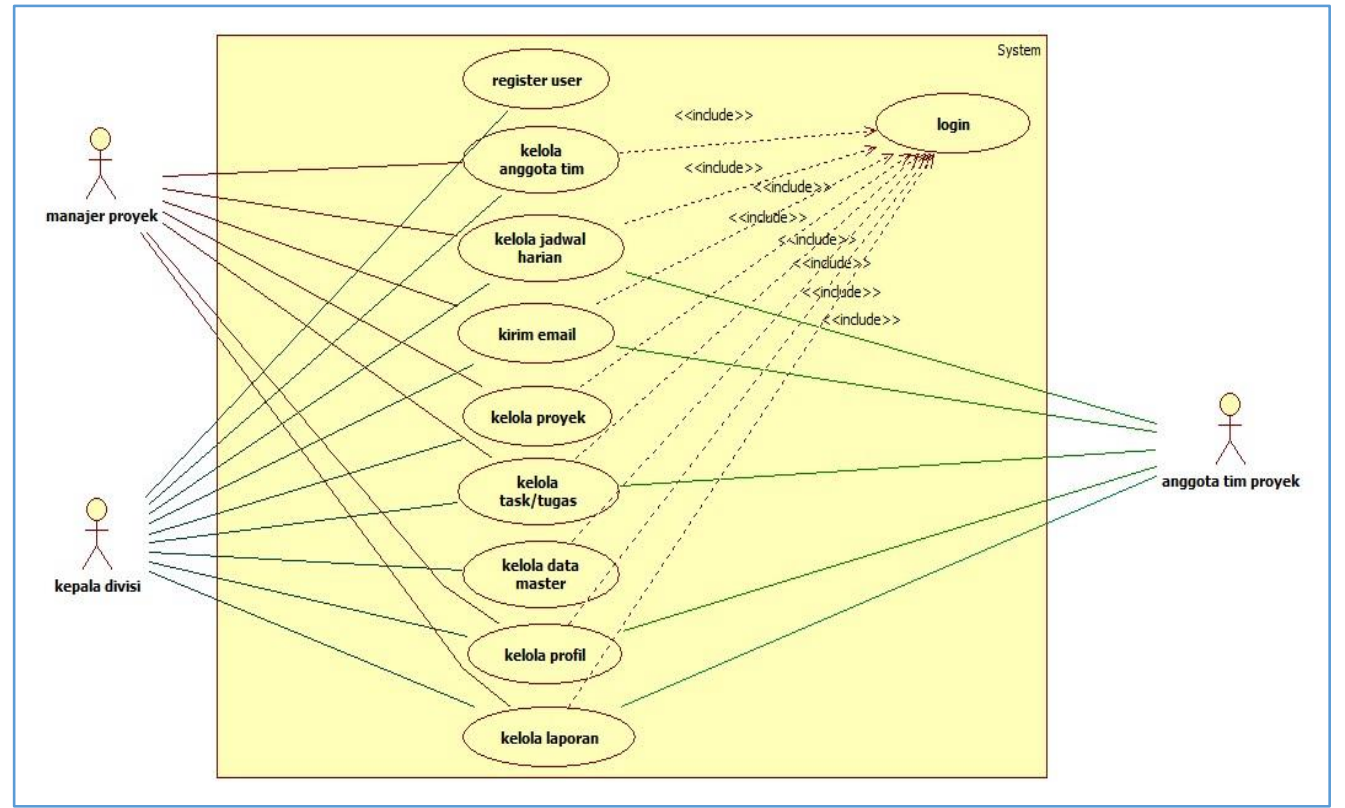

Gambar 1

Diagram System Use Case

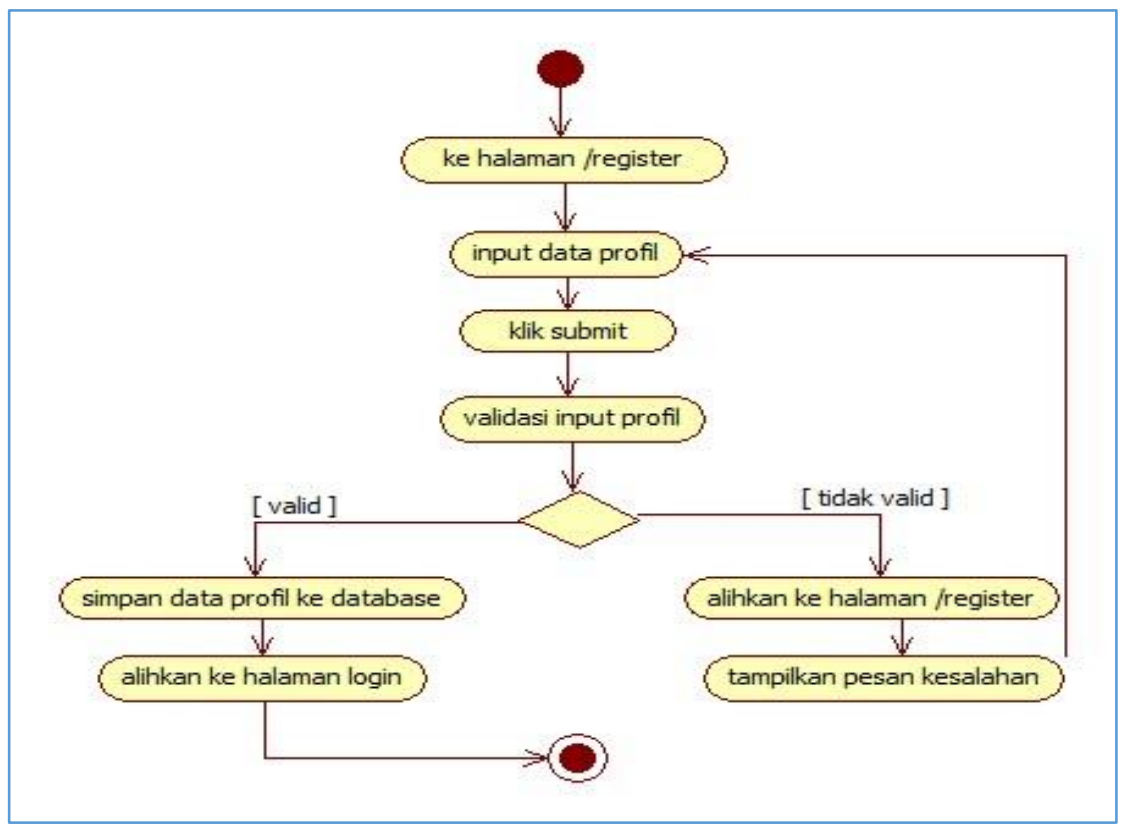

Gambar 2

Diagram Aktivitas Register User 


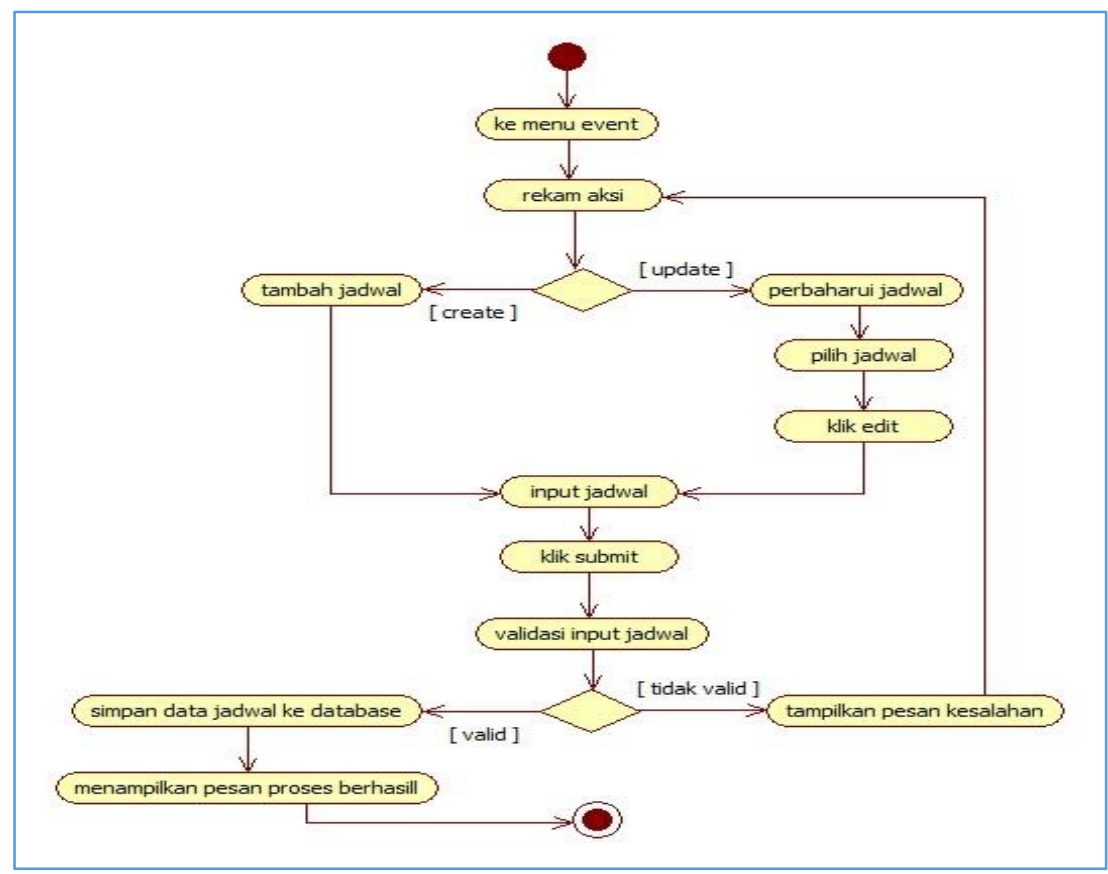

Gambar 3

Diagram Aktivitas Kelola Jadwal Harian

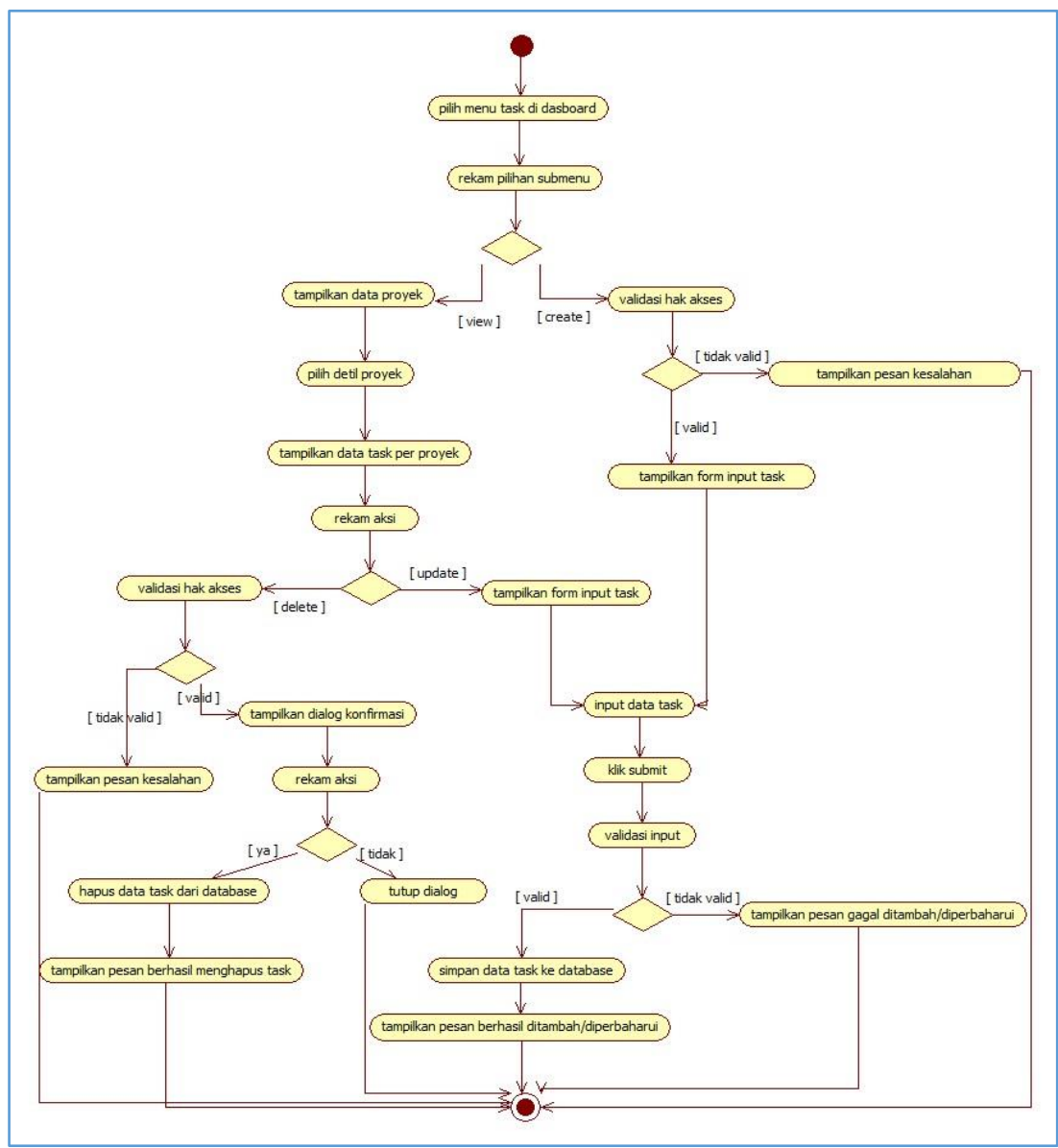

Gambar 4

Diagram Aktivitas Kelola Task 


\section{PERANCANGAN SISTEM}

Berdasarkan hasil analisis kebutuhan sistem, maka dibuat perancangan untuk sistem manajemen proyek berupa class diagram dan desain antar-muka.

Class diagram mendeskripsikan kumpulan class yang saling terkait. Class merupakan blueprint untuk menciptakan object. Setiap class berisi sejumlah atribut data dan method yang akan menentukan perilaku (behaviour) object. Class diagram ditampilkan pada Gambar 5.

Sedangkan desain antar-muka merupakan sketsa tampilan program aplikasi. Antarmuka yang dipersiapkan bisa berupa form-masukan, form-keluaran, layout laporan, atau struktur menu aplikasi. Hanya beberapa contoh rancangan antar-muka yang akan ditampilkan dalam artikel ini. Gambar 5 berisi desain struktur menu. Pada Gambar 6 dan 7 merupakan rancangan form untuk membuat task baru (create new task) dan proyek baru (create new project). Sedangkan Gambar 8 memuat desain form report view. Gambar 9 berisi contoh layout laporan, yaitu laporan kemajuan proyek (project progress report).

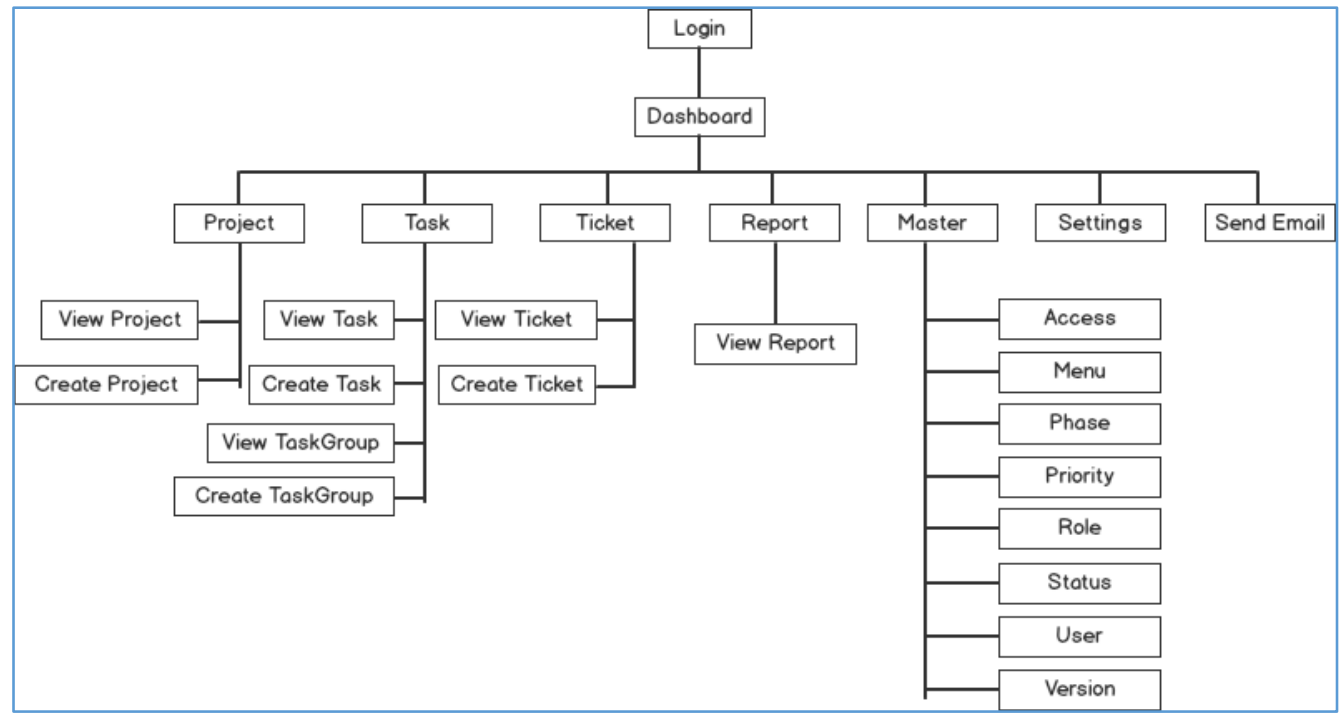

Gambar 5

Struktur Menu Aplikasi

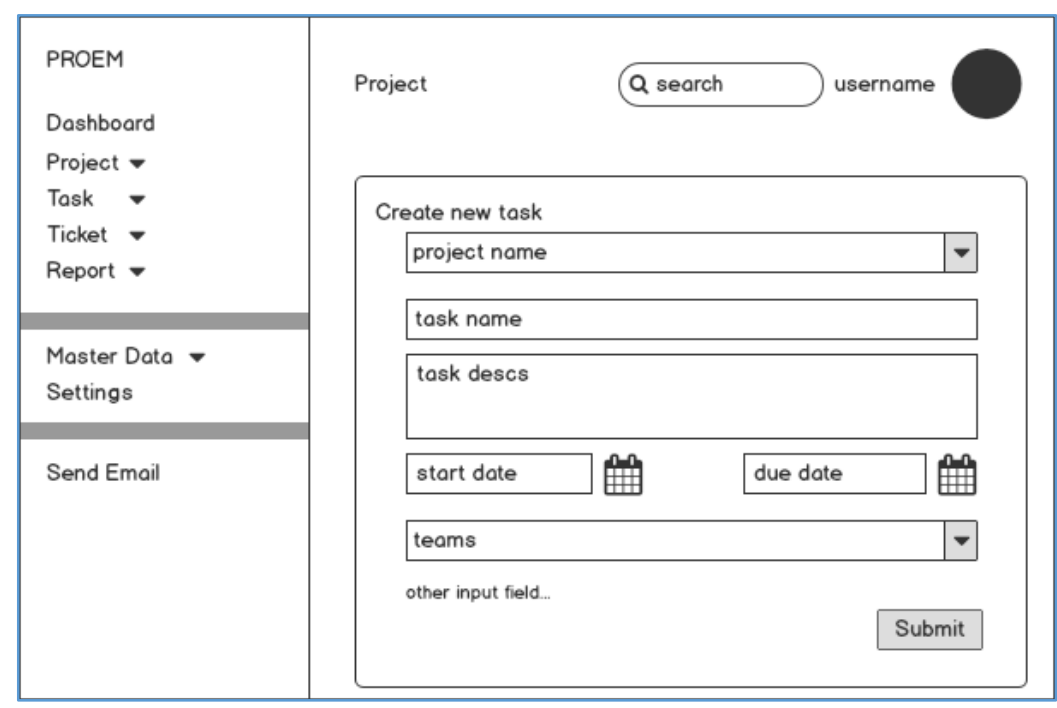

Gambar 6

Desain Form Create New Task 


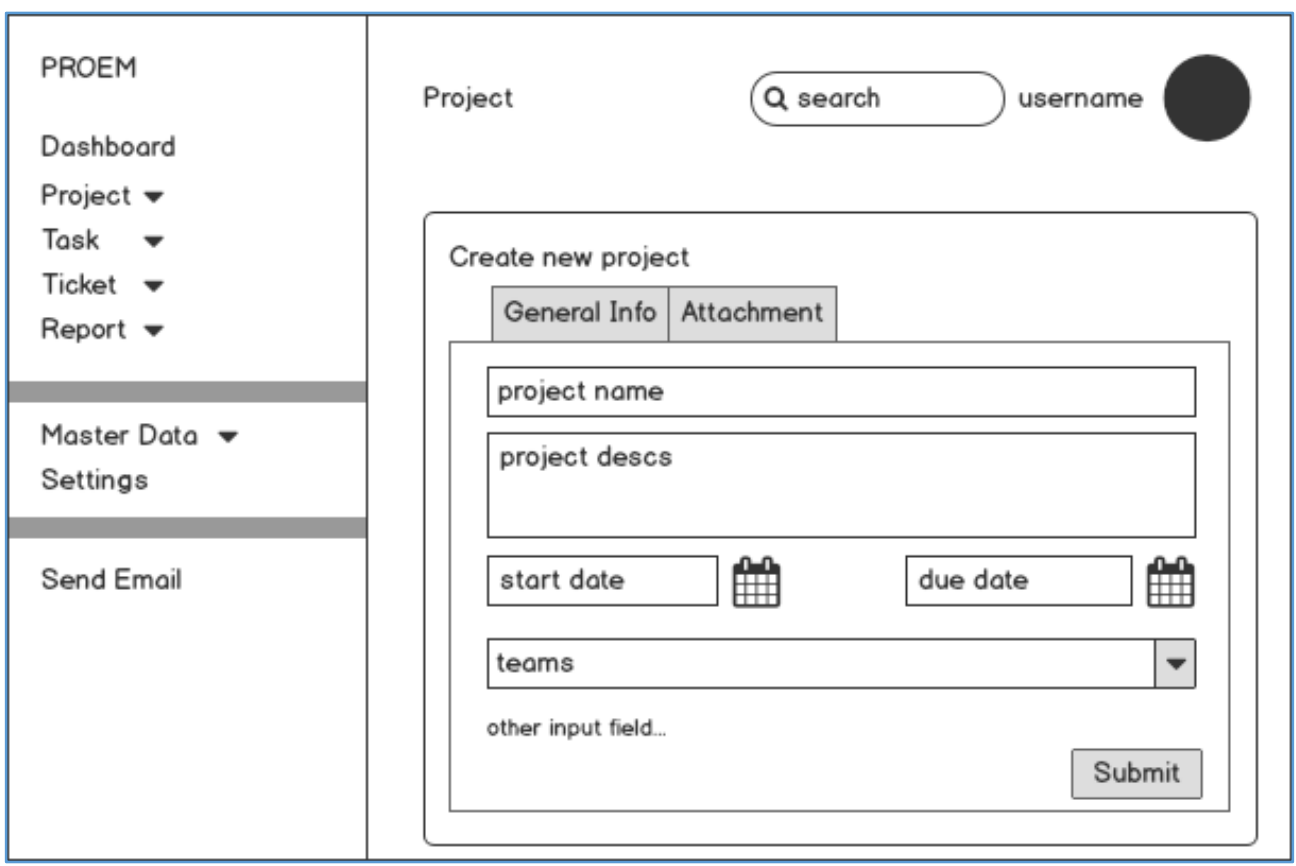

Gambar 7

Desain Form Create New Project

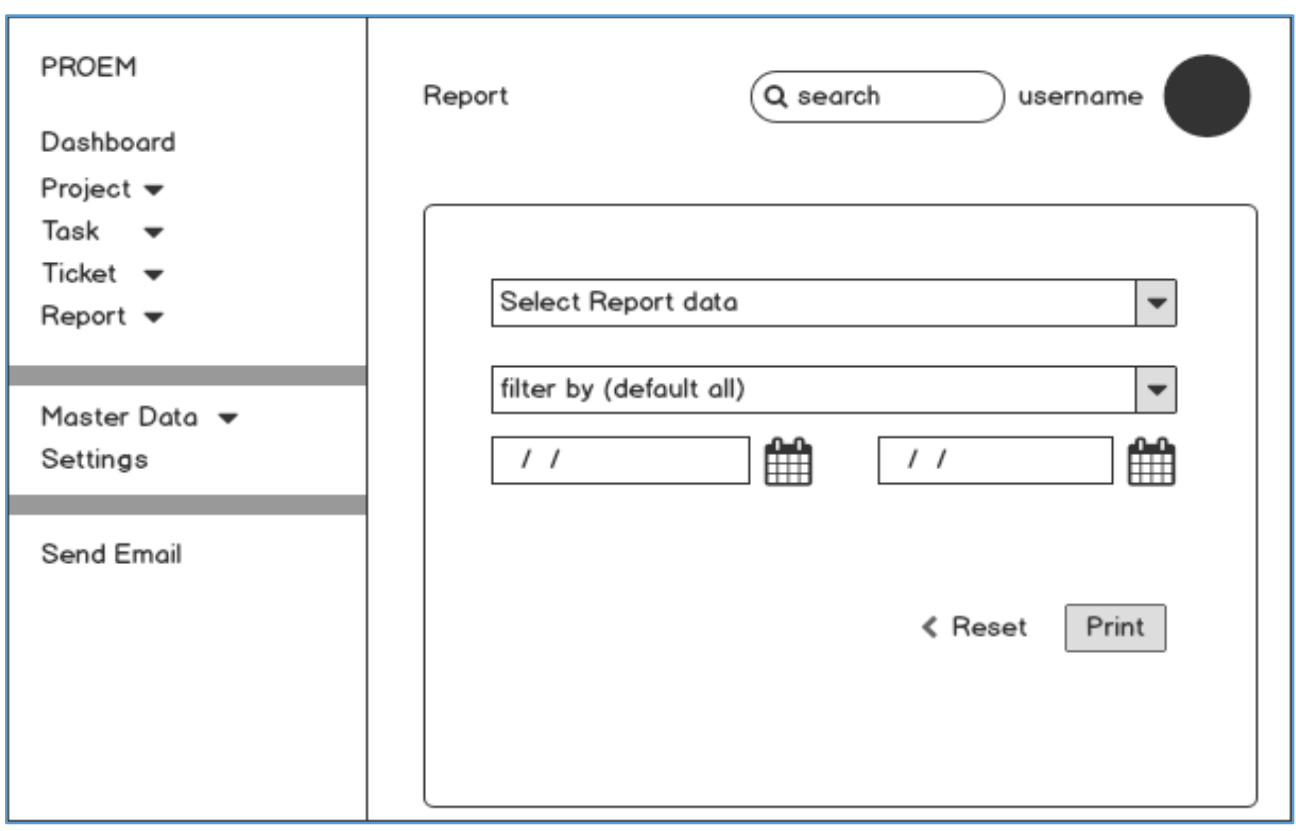

Gambar 8

Desain Form Report View 


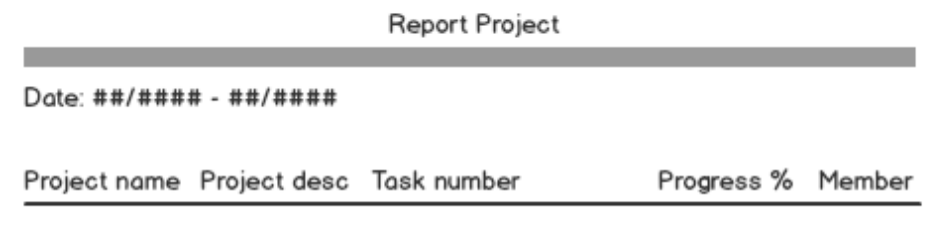

Gambar 9

Layout Laporan Kemajuan Proyek

\section{IMPLEMENTASI SISTEM}

Dalam tahap implementasi akan dipaparkan rancangan akhir sistem berupa component diagram dan deployment diagram.

Component diagram memuat gambaran keterkaitan antar komponen-komponen dalam perangkat lunak (program) yang akan dibangun. Terdapat empat main packages yaitu package factory (logika proses), controller (hubungan antar tampilan dan logika), models (class data) dan view packages (tampilan).

Sedangkan dalam deployment diagram digambarkan keterkaitan antar node (elemenelemen perangkat keras). Sebuah node dikaitkan dengan node lainnya melalui media communication associations.

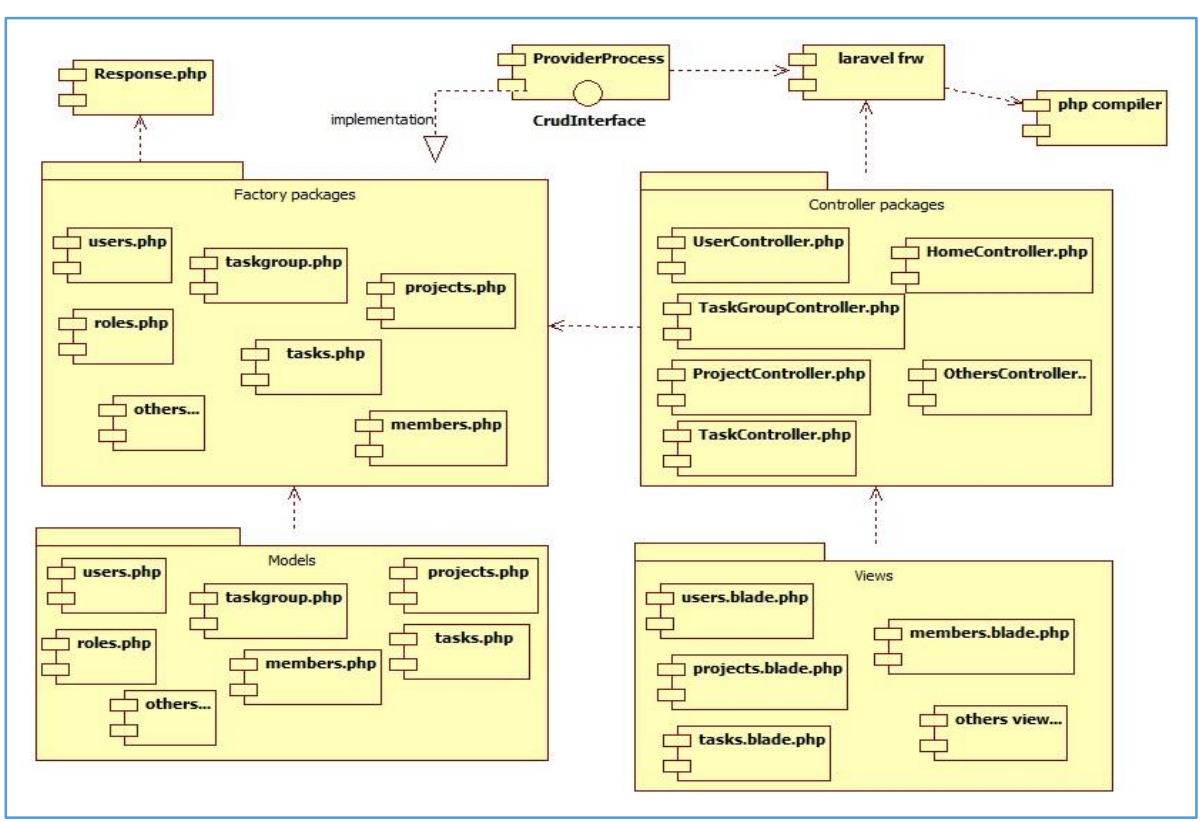

Gambar 10

Component Diagram 


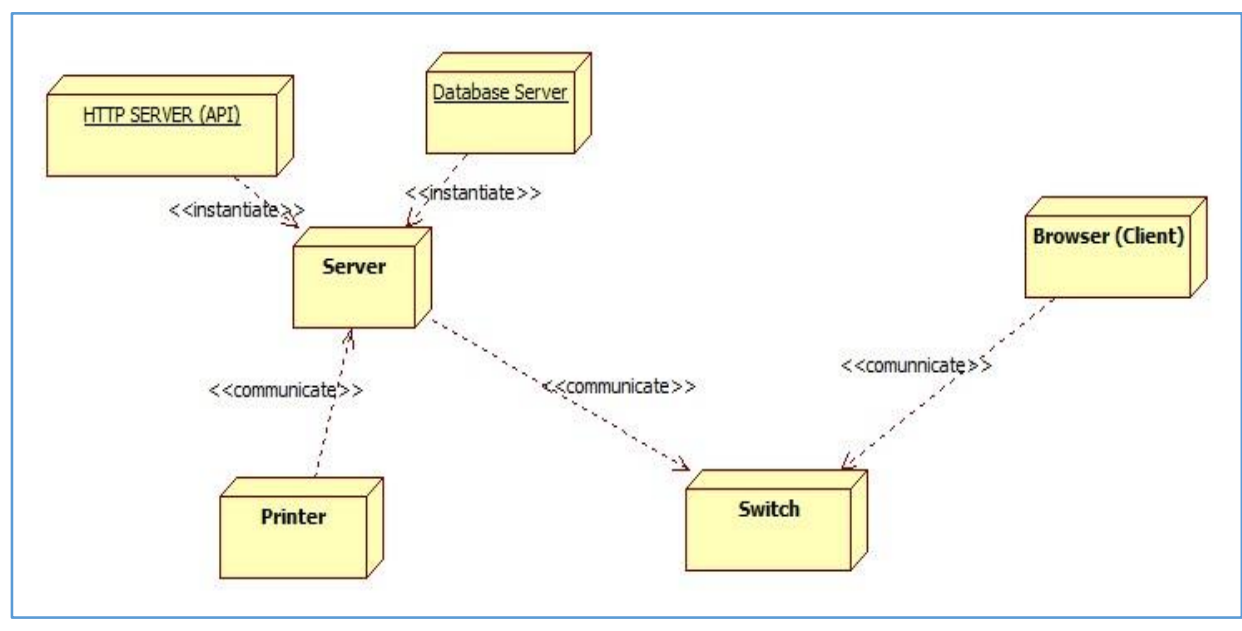

Gambar 11

Deployment Diagram

\section{KESIMPULAN}

Pengembangan sistem manajemen proyek merupakan upaya solutif untuk mengoptimalkan proses pengelolaan proyek di SCCIC ITB, sehingga tujuan dan target setiap proyek dapat tercapai dengan batasan sumber daya yang tersedia.

Beberapa perbaikan kinerja pada sistem baru yaitu meliputi :

a. Proses pendelegasian dan penentuan pekerjaan menjadi lebih efektif karena dapat dilakukan melalui sistem baru secara otomatis dan terintegrasi, sehingga briefing tiap awal pengerjaan proyek dapat diminimalkan, dipangkas bahkan diadakan hanya sesekali.

b. Pengerjaan tasks/tugas telah jelas pembagiannya, tidak perlu lagi bertanya pada Project Learder/Manager yang bersangkutan untuk pembagian task/tugas ybs.. Adapun, proyek yang sedang dikerjakan akan terus ber-progress dan tidak terhambat (on holding).

c. Adanya deskripsi tasks/tugas proyek yang harus dikerjakan, sehingga status proyek atau tasks yang sedang/akan dikerjakan dapat diketahui dan diamati.

d. Adanya informasi mengenai proyek tertentu, karena kemajuan proyek yang telah ditambah atau perlunya modifikasi fitur telah ada dan tertuang dalam sistem baru, sehingga anggota tim atau pekerja baru tidak bingung dengan status proyek yang akan dikerjakannya.

e. Adanya info pembaharuan/kemajuan terhadap tasks/tugas yang sedang dikerjakan, sehingga seringkali bentrokan pekerjaan dan pengulangan (buat ulang) pengerjaan tasks/tugas diantara anggota proyek dapat diminimalisasi.

\section{DAFTAR PUSTAKA}

[1] Dimyati, Hamdan dan Nurjaman Kadar, 2014, Manajemen Proyek. Balikpapan : CV Pustaka Setia.

[2] O’Docherty, Mike, 2005, Object Oriented Analysis and Design : Understanding System Development with UML 2.0. Chichester : John Wiley \& Sons Ltd.

[3] --, 2003, Object Oriented Analysis and Design using UML. Santa Clara : Sun Microsystems, Inc. 